\title{
Manajemen Ektrakurikuler Futsal Sma Negeri Se- Kabupaten Jepara
}

\author{
${ }^{1}$ Moh Fahmi Khotib, ${ }^{2}$ Ibnu Fatkhu Royana, ${ }^{3}$ Utvi Hinda Zhannisa \\ Universitas PGRI Semarang, 50125, Indonesia. \\ fahmi032016@gmail.com, ibnufatkhuroyana@gmail.com, utvihindazhannisa@gmail.com
}

\begin{abstract}
It is still unknown whether the futsal extracurricular management in Jepara regency is the success of the futsal extracurricular. One of them is determined by management and some schools still do not carry out management functions in extracurricular activities. Therefore, this study aims to determine how the management of futsal extracurricular activities in SMA State Jepara Regency. This research uses qualitative research with a descriptive approach, with the research subjects namely coaches, trainers and students. Collecting data using interview, observation and documentation methods. Data analysis using methods that are carried out continuously with data reduction, data presentation and drawing conclusions. The results of the study are seen from the indicators: (1) Planning is said to have not been programmed properly, seen from the absence of planning in the program being made. Regarding funding, it is not yet detailed in the planning. (2) Organizing is said to be still not competent, seen from the absence of an organizational structure for futsal extracurricular activities. (3) The implementation is said to still experience obstacles in the training process such as the field often collides with other extracurricular activities. The available facilities and infrastructure are inadequate. (4) The supervision is said to have not been maximally carried out because the evaluation is fully left to the trainer. Based on the results of the study, it can be concluded that the extracurricular management of Futsal in SMA State Jepara including planning, organizing, mobilizing and monitoring has not been implemented properly. From the overall suggestion it can be concluded that, to the principal of SMA State in Jepara Regency and the management of the futsal extracurricular that oversees the futsal extracurricular activities of SMA State in Jepara Regency to be able to use the results of this research as input and information in order to improve management performance in order to continue to develop and improve the achievements of futsal extracurricular.
\end{abstract}

Keywords: Management, Extracurricular, Futsal

\section{Abstrak}

Manajemen ekstrakurikuler futsal SMA Negeri se - kabupaten Jepara masih belum diketahui, dimana keberhasilan ekstrakurikuler futsal. Salah satunya ditentukan oleh manajemen dan beberapa sekolah masih belum menjalankan fungsi manajemen dalam ekstrakurikuler. Maka dari itu, penelitian ini bertujuan untuk mengetahui bagaimana manajemen kegiatan ekstrakurikuler futsal SMA Negeri se- Kabupaten Jepara. Penelitian ini menggunakan penelitian kualitatif dengan pendekatan deskriptif, dengan subjek penelitian ini yaitu Pembina, Pelatih dan siswa. Pengumpulan data menggunakan metode wawancara, observasi dan dokumentasi. Analisis data menggunakan metode yang dilakukan secara terus menerus dengan reduksi data, penyajian data dan penarikan kesimpulan. Hasil penelitian dilihat dari indikator : (1) Perencanaan dikatakan belum terprogram dengan baik dilihat dari tidak adanya perencanaan dalam program yang dibuat. Mengenai pendanaan belum secara terperinci dalam perencanaan. (2) Pengorganisasian dikatakan masih belum berkompeten dilihat dari tidak adanya struktur organisasi kegiatan ekstrakurikuler futsal. (3) Pelaksanaan dikatakan masih mengalami hambatan dalam proses latihan seperti lapangan sering berbenturan dengan ekstrakurikuler yang lain. Sarana dan prasarana yang tersedia kurang memadai. (4) Pengawasan dikatakan belum maksimal dilakukan karena evaluasi sepenuhnya diserahkan kepada pelatih. Berdasarkan hasil penelitian dapat disimpulkkan bahwa Manajemen Ektrakurikuler Futsal SMA Negeri se- Kabupaten Jepara meliputi perencanaan, pengorganisasian, penggerakan dan pengawasan belum bisa terlaksana dengan baik. Dari saran keseluruhan dapat disimpulkan bahwa, kepada kepala sekolah SMA Negeri seKabupaten Jepara dan kepengurusan ektrakurikuler futsal yang menaungi ekstrakurikuler futsal SMA Negeri seKabupaten Jepara untuk dapat menggunakan hasil penelitian ini sebagai bahan masukan dan informasi dalam rangka meningkatkan kinerja manajemen agar terus mengembangkan dan meningkatkan prestasi dari ekstrakurikuler futsalnya.

Kata kunci : Manajemen, Ektrakurikuler, Futsal. 


\section{PENDAHULUAN}

Sebagai lembaga pendidikan, sekolah bertujuan untuk mendidik dan membina siswa agar dapat mengembangkan kemampuan, kecerdasan, dan keterampilan yang siswa miliki dalam segala bidang. Tentunya pembinaan dan proses pendidikan yang terarah dan berkoordinasi diperlukan demi mencapai prestasi belajar yang maksimal sehingga tercapainya tujuan pendidikan.

Sekolah sebagai lembaga pendidikan sesungguhnya tidak hanya berkewajiban mengembangkan dan meningkatkan kemampuan siswa dalam hal-hal yang bersifat akademik, tapi juga berkewajiban mengembangkan dan meningkatkan kemampuan siswa dalam hal-hal yang bersifat non-akademik pula, dalam artian pembinaan siswa yang tidak secara langsung berhubungan dengan pelajaran. Pada tataran non-akademik, sekolah harus memberikan tempat bagi tumbuh kembangnya beragam bakat dan kreativitas siswa sehingga mampu membuat siswa menjadi manusia yang memiliki kebebasan berkreasi yang salah satunya melalui kegiatan ekstrakurikuler (Ruliyanto Ratno Saputro dkk, 2017:49).

Menurut Permendikbud Nomor 62 Tahun 2014 tentang Kegiatan Ekstrakurikuler Pada Pendidikan Dasar dan Pendidikan Menengah "Kegiatan Ekstrakurikuler adalah kegiatan kurikuler yang dilakukan oleh peserta didik di luar jam belajar kegiatan intrakurikuler dan kegiatan kokurikuler, di bawah bimbingan dan pengawasan satuan pendidikan, bertujuan untuk mengembangkan potensi, bakat, minat, kemampuan, kepribadian, kerjasama, dan kemandirian peserta didik secara optimal untuk mendukung pencapaian tujuan pendidikan".

Ekstrakurikuler dimaksudkan untuk mengembangkan salah satu bidang pelajaran yang diminati oleh sekelompok siswa. Misalnya olahraga, kesenian, dan berbagai macam ketrampilan lain. Dilihat dari manfaatnya banyak sekali manfaat jika mereka mengikuti kegiatan ekstrakurikuler di luar jam sekolah: 1) Siswa mampu meningkatkan kemampuan dan kreativitas sesuai dengan potensi, bakat dan minat mereka, 2) Siswa dapat mengembangkan kemampuan berinteraksi sosial kepada siswa lain, 3) Siswa dapat membuat suasana rileks, menggembirakan dan menyenangkan yang diakibatkan dari kegiatan proses pemebelajaran akademik, 4) dapat meningkatkan prestasi belajar siswa di sekolah.

Olahraga merupakan bentuk kegiatan yang bermanfaat dan dapat meningkatkan kesegaran dan kebugaran jasmani. Selain untuk membentuk watak, perilaku, keperibadian, disiplin dan spotifitas, olahraga juga dapat meningkatkan kemampuan daya pikir serta perkembangan prestasi optimal. Olahraga adalah salah satu bentuk dari upaya manusia yang diarahkan pada pembentukan kepribadian, serta sportivitas yang tinggi, dan dikembangkan pada peningkatan kualitas dan prestasi.

Dari sekian banyak ektrakurikuler yang ada disekolah, cabang olahraga futsal adalah paling populer dan banyak digemari oleh peserta didik. Futsal merupakan salah satu cabang olahraga yang harus dibina dan dikembangkan. Futsal adalah olahraga yang dilakukan oleh individu yang bergabung dalam satu tim, hal ini yang menuntut kemampuan masing-masing individu yang lain sehingga dapat memenangkan setiap permainan (Ainur Rofiq, 2015:2). Kemampuan individu meliputi kemampuan 
taktik, teknik, fisik serta mental yang perlu dikembangkan.

Keadaan yang saat ini terjadi, sebagian pihak masih belum menyadari arti pentingnya manajemen atau pengelolaan kegiatan ekstrakurikuler khususnya dibidang olahraga. Kenyataan yang terjadi dilapangan, memperlihatkan bahwa kegiatan ektrakurikuler mendapatkan proporsi yang tidak seimbang, kurang diberikan perhatian, bahkan cenderung disepelekan. Perhatian sekolah-sekolah masih banyak yang kurang serius, permasalahan seperti ini terlihat dari kurang dukungan yang memadai baik dari segi pendanaan, perencanaan dan pelaksanaan, serta berperan sebagai mengevaluasi tingkat keberhasilan siswa. Untuk mencapai tujuan sebagaimana mestinya, pihak sekolah dan pengurus ekstrakurikuler dituntut untuk mengerti bagaimana cara mengelola semua hal yang ada keterkaitannya dengan program ekstrakurikuler khususnya ekstrakurikuler olahraga futsal. Dengan demikian pemahaman dan pengelolaan ektrakurikuler yang baik akan membentuk karakter siswa yang kreatif, inovatif, dan beradab.

Di Kabupaten Jepara terdapat 10 SMA Negeri dan beberapa sudah menjalankan kegiatan ekstrakurikuler olahraga futsal untuk menyalurkan potensi yang dimiliki para siswa. Adapun di SMA Negeri se-Kabupaten Jepara pasti terdapat sebuah manajemen yang mengatur ekstrakurikuler futsal tersebut. Pengelolaan ekstrakurikuler futsal itu sendiri terdapat fungsi - fungsi seperti fungsi perencanaan, pengorganisasian, pengendalian serta pengawasan. Didalam sebuah ekstrakurikuler futsal pengelolaan sebuah tim akan berhasil jika fungsi- fungsi tersebut dapat berjalan dengan baik.

Berdasarkan rumusan masalah tersebut maka tujuan penelitian yang terdapat pada penelitian ini yaitu untuk mengetahui manajemen ekstrakurikuler futsal yang ada di SMA Negeri se-Kabupaten Jepara.

\section{METODE}

Dalam penelitian ini menggunakan metode kualitatif yang bertujuan untuk mengetahui dan mengkaji lebih dalam tentang pengelolaan ekstrakurikuler futsal yang ada di SMA Negeri se-Kabupaten Jepara. Penelitian deskriptif termasuk dalam penelitian kualitatif yang bertujuan mendeskripsikan peristiwa dan fakta lapangan. Teknik pengambilan sampel dalam penelitian ini adalah teknik purposive sampling. Dengan menggunakan pendekatan ini peneliti diharapankan bisa memaparkan, mendeskripsikan dan menguraikan yang nanti hasilnya akan dituangkan dalam bentuk suatu laporan dan penjelasan tentang bagaimana manajemen ektrakurikuler futsal SMA Negeri se-Kabupaten Jepara. 
Penelitian ini akan dilakukan di ektrakurikuler futsal SMA Negeri se-Kabupaten Jepara, meliputi :

1. Ektrakurikuler futsal SMA Negeri 1 Jepara,

2. Ektrakurikuler futsal SMA Negeri 1 Tahunan,

3. Ektrakurikuler futsal SMA Negeri 1 Pecangaan,

4. Ektrakurikuler futsal SMA Negeri 1 Mayong,

5. Ektrakurikuler futsal SMA Negeri 1 Welahan,

6. Ektrakurikuler futsal SMA Negeri 1 Nalumsari,

7. Ektrakurikuler futsal SMA Negeri 1 Bangsri,

8. Ektrakurikuler futsal SMA Negeri 1 Kembang,

Instrument penelitian merupakan sarana fasilitas bahan yang digunakan peneliti yang berisi proses pengumpulan untuk memudahkan dalam memperoleh hasil penelitian (Sugiyono, 2016:305). Instrument yang digunakan harus divalidasi seberapa jauh penelitian kualitatif siap melakukan penelitian selanjutnya. Dalam penelitian ini menggunakan teknik observasi wawancara dan dokumentasi.

Menurut Bogdan dalam Sugiyono (2017:334) analisi data adalah proses mencaridan menyusun secara sistematis data yang diperoleh dari hasil wawancara, catatan lapangan dan bahan-bahan lain, sehingga dapat mudah dipahami dan temuannya dapat diinformasikan kepada orang lain.

1. Reduksi Data (Data Reduction)

Reduksi data menurut Sugiyono (2017:339) merupakan proses berfikir sensitive yang memerlukan kecerdasan dan keluasan dan kedalaman wawasan yang tinggi. Proses reduksi data adalah pengurangan data dalam penelitian untuk lebih memetingkan hasil yang diamati. Setelah data terakumulasi semua kemudian dipilih data yang tidak sesuai atau tidak sinkron untuk direduksi. Selama proses reduksi bekerja maka reduksi ini memanfaatkan dalan memfokuskan data yang diteliti dan berikutnya ditarik sebuah kesimpulan.

2. Penyajian Data (Data Display)

Menurut Sugiyono (2017:341) dalam penelitian kualitatif, penyajian data bisa dilakukan salam bentuk uraian singkat, hubungan antar kategori, flawchart dan sejenisnya. Yang paling sering digunakan untuk menyajikan data dalam penelitian kualitatif adalah dengan teks yang bersifat naratif. Dalam langkah ini proses penyajian data adalah untuk mengetahui apa yang sedang dialami dan apa yang perlu diketahui untuk penyajian data yang tidak penting.

3. Penarikan Kesimpulan dan Verifikasi

Penarikan kesimpulan atau verifikasi merupakan suatu tahap atau proses pengambilan kesimpulan terhadap teori atau temuan baru yang belum pernah ada yang bertolak dari pernyataanpernyataan penelitian dan tujuan yang senantiasa diperiksa kebenarannya selama penelitian berlangsung untuk keabsahan data.

Menurut Sugiyono (2017:345) kesimpulan dalam penelitian kualitatif yang diharapkan berupa 
temuan baru yang sebelumnya belum pernah ada. Temuannya dapat berupa deskripsi atau gambaran suatu obyek yang sebelumnya masih remang-remang atau gelap sehingga setelah diteliti menjadi jelas, dapat berupa juga hubungan kausal atau interaktif, hipotesis atau teori.

\section{HASIL DAN PEMBAHASAN}

\section{HASIL PENELITIAN}

1. Perencanaan ekstrakurikuler futsal SMA Negeri se- Kabupaten Jepara sudah mempunyai tujuan yang jelas dengan terus menekankan pada penyaluran hobi siswa dalam mengembangkan bakat dan minat siswa serta mencetak bibit-bibit baru olahragawan yang berprestasi, mulai dari perekrutan pelatih dilakukan dengan merekrut alumni yang berasal dari sekolah tersebut sedangkan perekrutan siswa dengan cara mensosialisasikan melalui promosi. Tetapi terkait program latihan semua pelatih tidak membuat program latihan melainkan bersifat kondisional. Serta mengenai pendanaan belum secara terperinci begitu jelas dalam pengelolaannya dikarenakan proses pengelolaannya yang bersifat privasi bagi sekolah.

2. Pengorganisasian dalam kegiatan ekstrakurikuler futsal SMA Negeri se- Kabupaten Jepara sudah ada penanggung jawab masing-masing. Tetapi semua serempak tidak mempunyai struktur organisasi kegiatan ekstrakurikuler olahraga yang tertulis.

3. Penggerakan ekstrakurikuler futsal SMA Negeri se- Kabupaten Jepara sesuai jadwal yang telah direncanakan dan dengan didukung antusiasme siswa dalam latihan. Tetapi dalam proses latihan terjadi beberapa hambatan seperti terbenturnya jadwal ektrakurikuler, sarana dan prasarana serta komunikasi.

4. Pengawasan kegiatan ekstrakurikuler futsal SMA Negeri se- Kabupaten Jepara terdapat beberapa hal kekurangan karena evaluasi sepenuhnya diserahkan kepada pelatih mengakibatkan pembina kurang mengetahui kendala yang ada di lapangann sehingga kurang efektif dalam melakukan pengawasan.

\section{PEMBAHASAN}

1. Perencanaan

Berdasarkan penelitian yang dilakukan, perencanaan kegiatan ekstrakurikuler olahraga didalam perekrutan pelatih dilakukan dengan merekrut alumni yang berasal dari dalam sekolah yang dirasa berkompeten dalam bidang olahraga futsal untuk membantu melatih di ektrakurikuler disekolah. Kemudian untuk perekrutan siswa dalam kegiatan ekstrakurikuler futsal SMA Negeri seKabupaten Jepara yang diawali dari mensosialisasikan kegiatan siswa melalui promosi yang bertujuan untuk menumbuhkan minat peserta didik baru terjun dan terlibat aktif dalam kegiatan ektrakurikuler futsal yang ada disekolah SMA Negeri se- Kabupaten Jepara.

Mengenai program sejauh ini perencanaan program yang disusun untuk kemajuan 
ekstrakurikuler kurang baik terutama pada program latihan yang tidak disusun oleh pelatih melainkan bersifat kondisional. Dalam Perencanaan program latihan yang dilakukan ekstrakurikuler futsal semua SMA Negeri se-Kabupaten Jepara pelatih tidak membuat program latihan yang dibukakan secara fisik, sehingga kurang tersusunnya program latihan yang nantinya dilakukan mulai dari jangka panjang dan jangka pendek. Kemudian terkait perencanaan pendanaan sumber dana yang digunakan dari dana BOS, untuk pengelolaan dana secara terperinci belum begitu jelas dalam penyusunan proposal yang dilakukan di semua sekolah ekstrakurikuler futsal SMA Negeri seKabupaten Jepara. Pengajuan dana seperti honor koordinator, pengelola, dan pelatih kegiatan ekstrakurikuler.

2. Perencanaan

Pengorganisasian sangat penting dalam fungsi manajemen dan juga kegiatan ekstrakurikuler futsal. Pengorganisasia yang dilaksanakan ekstrakurikuler futsal SMA Negeri se- Kabupaten Jepara serempak tidak mempunyai struktur organisasi yang tertulis dan terstruktur. Sehingga dalam pelaksanaannya banyak peserta didik yang tidak mengetahui struktur kepengurusan kegiatan ekstrakurikuler olahraga di masing masing sekolah. Dalam kepengurusan ekstrakurikuler futsal semua SMA Negeri se- Kabupaten Jepara tidak dibentuk khusus untuk kegiatan ekstrakurikuler. Pengurus dibentuk berdasarkan tugasnya di sekolah. Tidak adanya pembentukan pengurus secara menyeluruh. pengurus antar unit mampu bekerja sama dan bersinergi menjalankan tugasnya. Kerjasama untuk koordinasi yang dilakukan di awal tahun antara pembina dan pelatih dalam mendapatkan kesepakatan mengenai kebijakan apa yang akan diterapkan dalam ekstrakurikuler futsal.

3. Penggerakan

Pelaksanaan kegiatan ekstrakurikuler futsal SMA Negeri se- Kabupaten Jepara dikatakan sudah berjalan sesuai dengan jadwal yang sudah ditentukan. Beberapa kendala yang ada pada saat latihan yaitu kendala lapangan karena sering berbenturan dengan ekstrakurikuler yang lain sehingga harus sewa lapangan latihan ekstrakurikuler futsal. Dan hambatan lainnya adalah kurangnya komunikasi interaksi aktif antara siswa dengan pembinanya. Karena kebanyakan sekolah SMA Negeri di Kabupaten Jepara pembina ekstrakurikuler futsal kurang aktif dalam kegiatan ekstrakurikuler futsal. Walaupun interaksi aktif untuk berkomunikasi antara siswa dengan siswa lainnya dan antara siswa dengan pelatih pada ekstrakurikuler berjalan dengan baik untuk bekerja sama dalam membentuk dan melatih kerja sama dalam kegiatan ekstrakurikuler.

Terkait dengan sarana dan prasarana yang ada di ekstrakurikuler futsal SMA Negeri seKabupaten Jepara belum memadai. Sarana seperti bola, cone, rompi yang masih kurang dalam pelaksanaan dan prasarana lapangan ekstrakurikuler futsal SMA Negeri se- Kabupaten Jepara tidak mempunyai lapangan yang pembuatannya memenuhi standart. Dengan terbatasnya sarana dan prasana yang dimiliki oleh SMA Negeri se- Kabupaten sehingga mengakibatkan proses kegiatan 
latihan tidak bisa dilakukan secara efektif dan efesien dalam proses latihan.

4. Pengawasan

Berdasarkan penelitian yang dilakukan, pengawasan pada kegiatan ekstrakurikuler futsal SMA Negeri se- Kabupaten Jepara belum dapat dikatakan baik dilihat dari kurang aktifnya pembina dalam pengawasan kegiatan ekstrakurikuler futsal. Salah satunya adalah tanggung jawab pada tugasnya setidaknya pembina hadir dalam kegiatan ekstrakurikuler olahraga, walaupun tidak semua SMA pembinanya kurang aktif. Untuk evaluasi hampir semua pelatih melaksanakan evaluasi setelah kegiatan ekstrakurikuler futsal berakhir. Evaluasi yang dilaksanakan pelatih ektrakurikuler futsal SMA Negeri se- Kabupaten Jepara lebih menekankan terkait dengan penanaman karakter, penguatan materi dan pengarahan teknik yang benar pada saat proses latihan ektrakurikuler futsal Adanya evaluasi setelah kegiatan juga sangat penting, karena dengan selalu adanya evaluasi, para peserta ekstrakurikuler futsal akan memahami dan mengerti mana hal yang benar dan mana hal yang salah.

\section{KESIMPULAN}

Kesimpulan

Berdasarkan hasil penelitian dan pembahasan, maka dapat disimpulkan bahwa Manajemen Ektrakurikuler Futsal SMA Negeri se- Kabupaten Jepara meliputi perencanaan, pengorganisasian, penggerakan dan pengawasan belum bisa terlaksana dengan baik. Masih terdapat beberapa kendala mulai dari progam latihan, pendanaan, struktur organisasi, komunikasi, sarana dan prasarana serta evaluasi. Tetapi sudah ada beberapa yang terlaksana meliputi perumusan tujuan, penerimaan pelatih dan siswa, koordinasi, antusiasme siswa pada saat kegiatan ektrakurikuler futsal dan pengukuran pelaksanaan.

Saran

Berdasarkan penelitian dan hasil kesimpulan dapat disimpulkan bahwa, kepada kepala sekolah SMA Negeri se- Kabupaten Jepara dan kepengurusan ektrakurikuler futsal yang menaungi ekstrakurikuler futsal SMA Negeri se- Kabupaten Jepara untuk dapat menggunakan hasil penelitian ini sebagai bahan masukan dan informasi dalam rangka meningkatkan kinerja manajemen agar terus mengembangkan dan meningkatkan prestasi dari ekstrakurikuler futsalnya. 


\section{DAFTAR PUSTAKA}

Akhmadi, T \& Indriarsa, N. (2013). "Survei Manajemen Ekstrakurikuler Futsal Smp Negeri 4 Sidoarjo". Jurnal Pendidikan Olahraga dan Kesehatan. Volume 01 Nomor 02, 411 - 414.

Arikunto, S. (2014). Prosedur Penelitian. Jakarta: PT Rineka Cipta

Arimbi, M. D. (2013). Manajemen Pengelolaan Fasilitas Futsal Di Kota Cilacap Tahun 2013. Skripsi. Universitas Negeri Semarang. Tidak diterbitkan.

Handoko, T. H. (2001). Manajemen Personalia dan Sumber Daya Manusia. Yogyakarta: BPFE

Handoko, T. H. (2003). Manajemen Personalia dan Sumber Daya Manusia. Yogyakarta: BPFE.

Handoko, T. H. (2015). Manajemen. Yogyakarta: BPFE

Harsuki. (2012). Pengantar Manajemen Olahraga. Jakarta: Rajawali Pers

Hasibuan, Malayu S. P. (2004). Manajemen. Jakarta: PT Bumi Aksara

Hinayatulohi, A. (2017). Manajemen Kkstrakurikuler Dalam Upaya Pengembangan Diri Santri Pondok Pesantren Al-Luqmaniyyah Yogyakarta. Skripsi. Universitas Islam Negeri Sunan Kalijaga Yogyakarta. Tidak diterbitka

Firdaus, H. (2017). Hakikat Futsal. Jakarta:

Harishfirdaus.blogspot.com/2017/01/hakekat-futsal.html?m=1

Lhaksana, J. (2011). Taktik dan Strategi Futsal Modern. Jakarta: Penebar Swadaya Group.

Manullang M. (2001). Manajemen Sumber Daya Manusia. Yogyakarta: BPFE

Masyitah, A. I. (2019). Analisis Manajemen Pembinaan Cabang Olahraga Pencak Silat Pengprov IPSI Sulawesi Selatan. Tesis. Sulawesi Selatan: Program Pasca Sarjana UNM. Tidak diterbitkan.

Mulyono, M. A. (2014). Buku Pintar Panduan Futsal. Banda Aceh: Laskar Aksara.

Prabowo, D. A \& Andrijanto, D. (2013). "Minat Siswa Dalam Mengikuti Ekstrakurikuler Futsal Studi Pada Siswa Peserta Ekstrakurikuler Futsal Di Smp Negeri 2 Buduran”. Jurnal Pendidikan Olahraga dan Kesehatan. Volume 01 Nomor 01, 92 - 97.

Prasetya, R. D. (2015). Manajemen Ekstrakurikuler Futsal Sma Negeri 4 Yogyakarta. Skripsi. Universitas Negeri Yogyakarta. Tidak diterbitkan

Prawiranegara, S. A \& Indriarsa, N. (2013). "Survei Manajemen Olahraga Pada Kegiatan Ekstrakurikuler Futsal Sma Sederajat Di Surabaya”. Jurnal Pendidikan Olahraga dan Kesehatan. Volume 01 Nomor 03, 558 - 561.

Rofiq, A. (2015). "Manajemen Konflik dalam Meningkatkan Kedisiplinan Guru (Studi Kebijakan di Smp Al-Kautsar Tanjungpinang Kepulauan Riau)”. Jurnal Aplikasi Manajemen. VI (2) 148-157. Saputri, H. D. (2016). Manajemen Ekstrakurikuler Untuk Mengembangkan Minat Dan Bakat Siswa Di Sd Muhammadiyah 1 Alternatif Kota Magelang. Skripsi. Universitas Islam Negeri Sunan Kalijaga Yogyakarta. Tidak diterbitkan 
Saputro, R. R. dkk. (2017). "Manajemen Ekstrakurikuler Non-Akademik Siswa di SMA Muhammadiyah 3 Jember". Jurnal Edukasi. IV(3): 49-53.

Setiasari, P. A. (2014). "Survei penerapan manajemen olahraga ektrakurikuler futsal di SMA Shafta Surabaya". Jurnal Pendidikan Olahraga dan Kesehatan. Vol 2 (1) 297-300.

Siswanto. (2005). Manajemen Tenaga Kerja Indonesia. Jakarta: PT Bumi Aksara

Siswanto, H. (2013). Manajemen Walet Muda Futsal Akademi Kabupaten Kebumen Tahun 2012/2013. Skripsi. Universitas Negeri Semarang. Tidak diterbitkan

Sugiyono. (2017). Metode Penelitian Pendidikan. Bandung: Alfabeta

Suprihanto, J. (2001). Manajemen Personalia. Yogyakarta: BPFE

Terry, G. R. (2013). Dasar-Dasar Manajemen. Bandung: Alfabeta

Tomo, R. A. (2015). Manajemen Badan Futsal Banjarnegara (Biro Futsal Naungan Pengcab Pssi Kabupaten Banjarnegara Tahun 2014). Skripsi. Semarang: Universitas Negeri Semarang. Tidak diterbitkan.

Undang-Undang No. 3 tahun 2005 tentang Sistem Keolahragaan Nasional

Wahab, A. A. (2007). Metode dan Model-Model Mengajar. Bandung: Alfabeta 